\title{
Synergia jako kryterium oceny projektów rewitalizacji śródmieść
}

\author{
Adam Derlatka \\ Instytut Projektowania Miast i Regionów, Wydziat Architektury, Politechnika Krakowska, \\ e-mail: aderlatka@gmail.com
}

Streszczenie: Celem wystąpienia jest omówienie i analiza efektów trzech programów rewitalizacji skupiających się na projektach urbanistyczno-architektonicznych w obrębie historycznie wykształconego śródmieścia. Projekty realizowane w ramach programów rewitalizacji powinny nieść za sobą zmiany dotykające całego obszaru zdegradowanego, wytwarzając wzajemne relacje o charakterze synergicznym, wynikające $\mathrm{z}$ wzajemnego powiązania projektów z tkanką miejską. W opracowaniu poddano analizie projekt rewitalizacji dotyczący bielskiej starówki (zrealizowany w ramach kompleksowego programu) z działaniami rewitalizacyjnymi w obrębie śródmieścia i Miasta Kazimierzowskiego w Radomiu oraz z podjętymi i planowanymi projektami na obszarze historycznego miasta w Rzeszowie. Autor dokonuje próby zdefiniowania na czym polega potencjalny efekt oddziaływania synergicznego w rewitalizacji. Zagadnienie synergii definiuje jako relację wytwarzaną między projektami rewitalizacji w przestrzeni śródmieścia oraz stopień wpisania ich w sieć przestrzeni publicznych i wzajemnej konfiguracji. Na koniec określa wnioski wynikające $\mathrm{z}$ tych relacji i oczekiwane efekty z nimi związane.

Słowa kluczowe: rewitalizacja, synergia, śródmieście.

\section{Wprowadzenie}

Potrzeba rewitalizacji miast narodziła się w Stanach Zjednoczonych, gdzie w latach $50 \mathrm{XX}$ wieku rozpoczęto wprowadzać wspólne działania administracji i sektora prywatnego, mające na celu ekonomiczne ożywienie zdegradowanych dzielnic. Pierwsze kompleksowe działania rewitalizacyjne w Polsce były poprzedzone licznymi doświadczeniami związanymi z rewaloryzacją, adaptacją i konserwacją istniejącej tkanki zabytkowej. Planowanie działań ożywiających jako rewitalizacji mającej na celu poprawę sytuacji danego obszaru zostały rozpoczęte w latach 90 XX w. Po przystąpieniu Polski do Unii Europejskiej dzięki środkom pochodzącym z ZPORR w latach 2004-2013 rozpoczęto tworzenie Lokalnych Programów Rewitalizacji (LPR). Obecnie termin rewitalizacji często jest błędnie używany dla określenia niezbędnych działań modernizacyjnych i rewaloryzacyjnych.

LPRy mimo, że są poprzedzone dogłębną analizą czynników lokalnych oraz nakreśleniem występujących procesów degradacji często ograniczają się do delimitacji obszarów, stref problemowych - określonych na podstawie wspomnianych kryteriów. W wielu przypadkach zawarty w nich program sprowadzał się do listy niezbędnych remontów, prac modernizacyjnych, przebudów oraz budowy nowej infrastruktury, prezentując działania niezbędne, rutynowe i zachowawcze. Często odbywało się to bez zapewnienia powiązania działań w spójną wizję wyprowadzenia obszaru z sytuacji kryzysowej. W nielicznych programach został uwzględniony "efekt mnożnikowy" uwzględniający koncentrację działań oraz relacje synergiczne. 
Zagadnieniem synergii w urbanistyce jako pierwszy w Polsce zajmował się Böhm Al. Badania prowadził na podstawie poszczególnych elementów budujących wnętrza urbanistyczne. Zauważył, że wartość wnętrza wytworzonego z poszczególnych elementów stanowi wyższą jakość niż zestaw wolnostojących elementów i jest elementem budującym krajobraz miasta. W kultywowaniu tych wartości Bohm odnajduje podstawy rewaloryzacji miast.

Odniesienie do zjawiska synergii odnajdujemy w programach rewitalizacji, gdzie jest ono sprecyzowane jako „efekt mnożnikowy” lub "efekt dźwigni”. Dotyczy relacji między projektami sektora publicznego i prywatnego, pozwalając na większe zintegrowanie i koncentrację działań w obszarach kryzysowych przez wspólną i partnerską współprace w ramach partnerstwa publiczno prywatnego (IRM, Tom 12)

Przedstawione podejście, polegające na wzajemnym powiązaniu projektów powinno być podstawowym kryterium zakładanym przy sporządzaniu programów rewitalizacji. Odpowiednia intensyfikacja działań pozwala na osiągnięcie wymaganej dla uzyskania trwałego efektu „masy krytycznej”. Zakładając, że wyraz przestrzenny centrum miasta europejskiego stanowi jego znak identyfikacji i jest wyrazem tożsamości, z którym mieszkańcy mogą się identyfikować (Gzell S.), autor pragnie spojrzeć na zagadnienie synergii jako relację między projektami w przestrzeni śródmieścia, wpisanymi w sieć przestrzeni publicznych.

\section{Synergia jako kryterium oceny projektów rewitalizacji}

Badając zagadnienie synergii między projektami w obrębie śródmieść należy postawić następujące pytania:

- Czy pomiędzy badanymi projektami występują relacje, które mogą mieć znamiona synergii?

- Czy relacje, o których mowa wiążą się w sposób logiczny z cechami struktury funkcjonalno - przestrzennej śródmieścia?

Interpretując postawione pytania w oparciu o analizowane przypadki projektów autor definiuje pojęcia: pole synergii oraz kierunki określające następujące relacje między projektami kluczowymi.

Pole synergii - niewielki centralny obszar operacyjny skupiony wokół projektu flagowego, w którym są prowadzone zintensyfikowane działania, w postaci wzajemnie powiązanych projektów.

Kierunki synergii -linowe zależności synergiczne - obszary powstałe na kierunkach integracji, głównie ulic śródmiejskich, na których następuje ożywienie wynikające z działań w skrajnie położonych polach synergii.

Budowanie strategii rewitalizacji $\mathrm{w}$ oparciu o powyższe założenia relacji synergii pomiędzy projektami powinno prowadzić do następujących efektów: zwiększenie tempa korzystnych zmian, większa efektywność uzyskiwania celów strategicznych rewitalizacji, wytworzenie korzystnych współzależności pomiędzy zmianami przestrzennymi (projektami) a zmianami społecznymi (nowa tożsamość, zaangażowanie lokalnej społeczności, wytworzenie więzi i poczucia odpowiedzialności za przestrzeń).

\section{Przypadki}

\subsection{Miasto Kazimierzowskie - Radom}

Przyczyny degradacji obszaru śródmieścia Radomia (IRM) zostały sklasyfikowane jako efekty negatywnych przekształceń przemysłu, usług i komunikacji skutkujące utratą 
podstawowych funkcji i zwartości przestrzennej. Gospodarcze podłoże procesu degradacji stało się przyczyną jej szybkiego pogłębienia także w sferach przestrzennej, społecznej i kulturowej. Zły stan techniczny znacznej części budynków w obrębie Miasta Kazimierzowskiego prowadził do konieczności przesiedlenia większości mieszkańców.

Działania rewaloryzacyjne w Radomiu rozpoczęte zostały już w latach 50 na terenie Miasta Kazimierzowskiego, kiedy stworzono koncepcję przestrzenną dla tego obszaru. Kolejne prace obejmowały projekt studialny z lat 1966 - 1967 autorstwa Chmielewskiego J.M. oraz Wejcherta K. Wartości zachowanego niemal w nienaruszonym stanie układu średniowiecznego zostały potwierdzone wpisem układu przestrzennego Miasta Kazimierzowskiego do rejestru zabytków w 1969 roku. Opracowano dokumentacje zabytkoznawczą pod kierunkiem Kalinowskiego W., który ukazał w literaturze światowej wartości radomskiego układu urbanistycznego. Prowadzone prace badawcze i studialne doprowadziły do stworzenia w 1979 roku przez zespół Instytutu Urbanistyki i Planowania Przestrzennego Uniwersytetu Warszawskiego (m.in. Adamczewska - Wejchert H., Chmielewski J.M., Wejchert K.) programu rewaloryzacji Miasta Kazimierzowskiego. W ocenie Kalinowskiego był to bardzo dobry projekt, godzący współczesne funkcje i potrzeby z historycznym charakterem miasta. Projekt wprowadzał nową zabudowę zachowując linie dawnych murów miejskich. Stał się także punktem do dyskusji nad potencjalnym problemem związanym z gentryfikacją, gdyż zakładano pomoc przy powrocie biedniejszych mieszkańców do swoich mieszkań. Niestety zakładany na 10 lat projekt z przyczyn kryzysu lat 80 i braku środków został jedynie częściowo zrealizowany poprzez budowę dwóch budynków mieszkalnych.

Powołana w 2003 roku miejska spółka z o.o. „Rewitalizacja” - jako koordynator prowadzi dalsze prace rewitalizacyjne na terenie Miasta Kazimierzowskiego. W tym czasie zostały opracowane dwa Programy Rewitalizacji. Pierwszy dla miasta Radomia, wyznaczający dwa obszary kryzysowe: śródmiejski o pow. 1054 ha (obręb całego śródmieścia) i Potkanów o pow. 7 ha. Drugi LPR dotyczy bezpośrednio Miasta Kazimierzowskiego. Spółka rozpoczęła działalność wg działań i zasad w nim zawartych dotyczących remontów elewacji i modernizacji kamienic, odbudowując wiele obiektów w obrębie Miasta Kazimierzowskiego np przy ul. Rwańskiej, Wąskiej, Wałowej oraz prowadzi rewaloryzacje przestrzeni publicznych np. atrakcyjny przestrzennie Skwer Unii Wileńsko - Radomskiej.
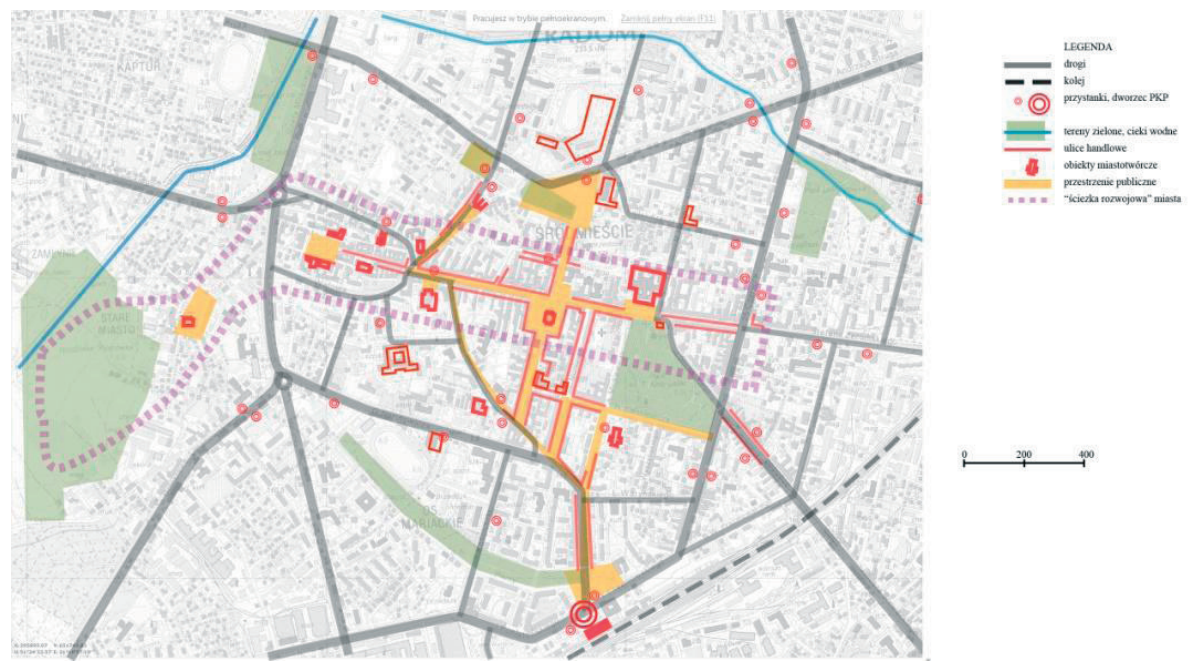

Rys. 1. Model przestrzenny struktury śródmieścia Radomia. Opracowanie własne 


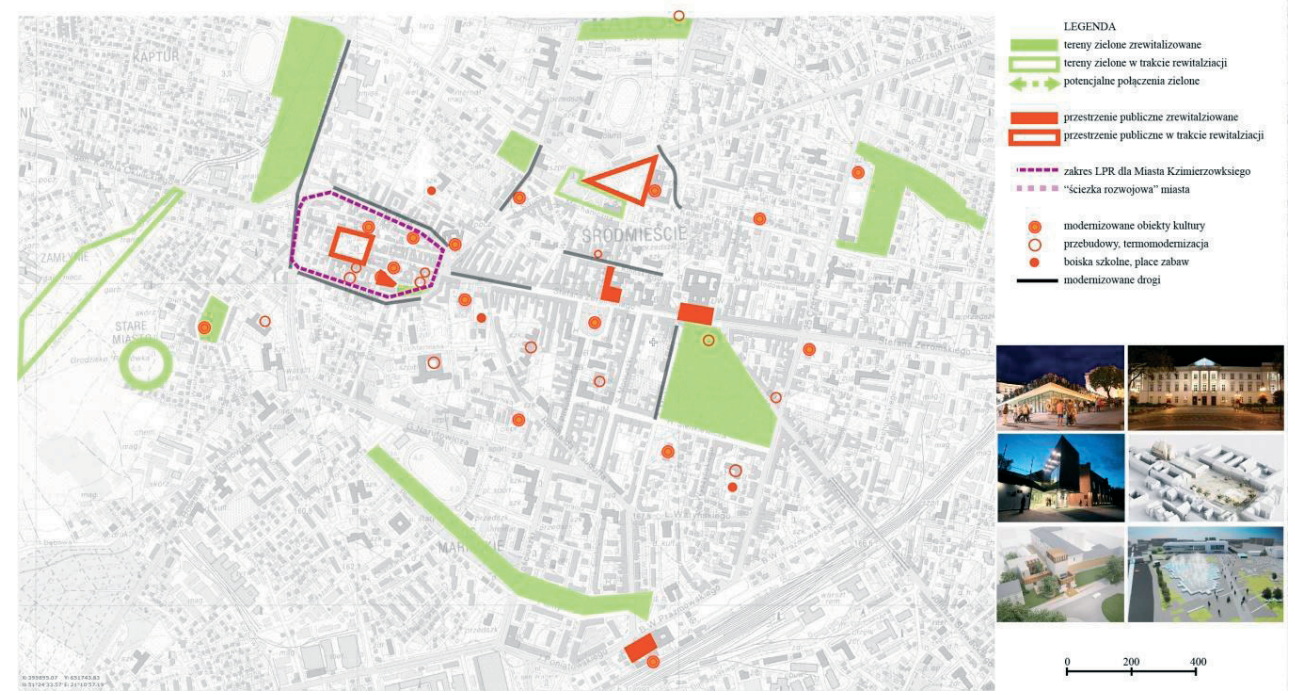

Rys. 2. Projekty rewitalizacji w obrębie MK i śródmieścia z LPR na lata 2007 - 2013. Opracowanie własne

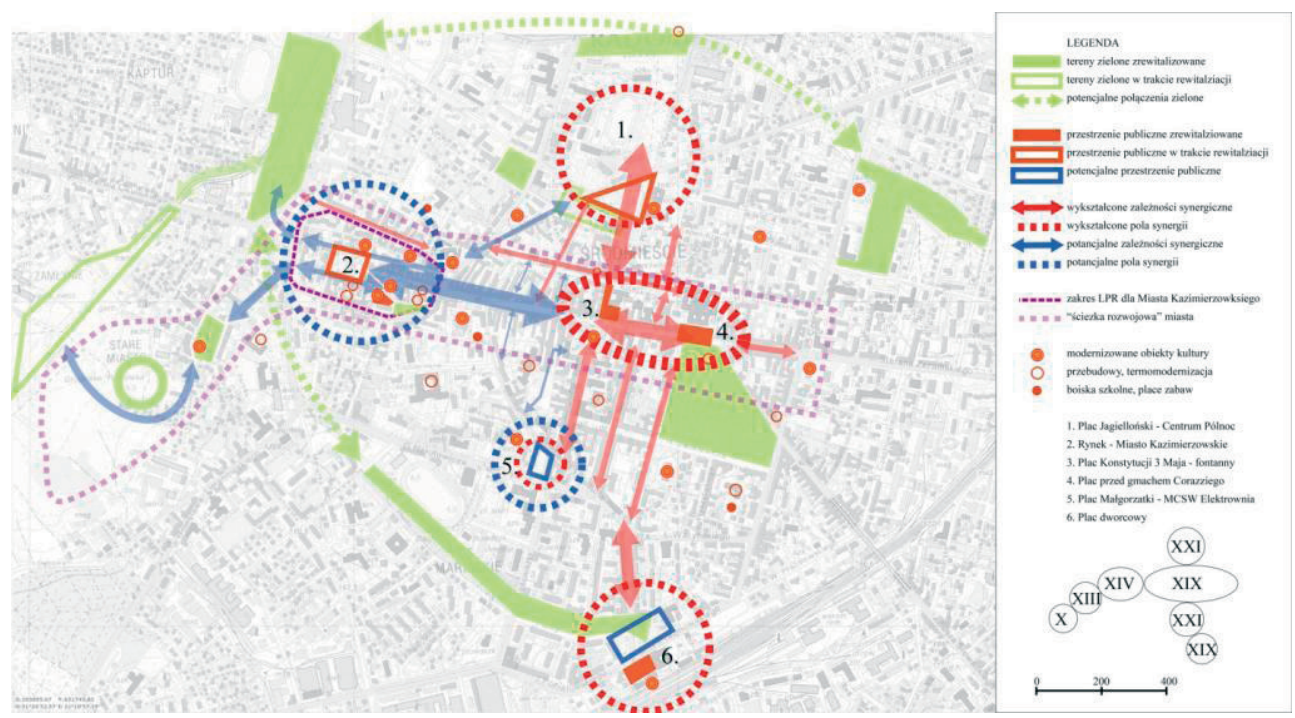

Rys. 3. Analiza wykształconych i potencjalnych zależności synergicznych. Opracowanie własne

Jako podstawę do analizy projektów rewitalizacji przyjęto sieć przestrzeni publicznych (rys. 1). Historycznie wykształcony układ osadniczy z czytelnymi kolejnymi etapami rozwoju miasta stanowi unikalną ścieżkę rozwojową z osią piszą śródmieścia wzdłuż ul. Żeromskiego. Projekty rewitalizacji w śródmieściu zostały podzielone na następujące kategorie dotyczące: przestrzeni publicznej, terenów zielonych, modernizację dróg i chodników, modernizację obiektów kultury, termomodernizacje, oraz obiekty sportowe i rekreacyjne (rys. 2). Zestawienie przedstawionych danych $\mathrm{z}$ faktycznym życiem miejskim śródmieścia pozwala wyznaczyć następujące wykształcone i potencjalne zależności synergiczne: 
Pole synergii Centrum Północ. Lokalizacja w północnej części śródmieścia dużego kompleksu handlowo-usługowo-mieszkaniowego - Galerii Słonecznej zmieniła istniejące kierunki strumieni ruchu z kierunku wschód zachód wzdłuż ul. Żeromskiego, na układ północ-południe (nowe centrum północ - plac konstytucji - dworzec). Dostępność komunikacyjna, sąsiedztwo placówek kultury (kino, teatr) oraz aspekty przestrzenne (projektowana rewitalizacja placu Jagiellońskiego) stanowią zaczątek nowego wielofunkcyjnego centrum miejskiego.

Pole synergii Centrum Plac Konstytucji 3 Maja - plac przed gmachem Corazziego. Działania rewitalizacyjne podjęte $\mathrm{w}$ śródmieściu skupiające się na utworzeniu atrakcyjnego deptaka wzdłuż ciągu wnętrz ulicy Żeromskiego spowodowały niewątpliwe ożywienie gospodarcze tego fragmentu miasta. Współczesny projekt przebudowy fontann, rodzący rozbieżne opinie mieszkańców i środowiska branżowego przyczynił się do podniesienia wartości przestrzeni publicznych stając się zwornikiem dwóch głównych ciągów pieszych śródmieścia. Istotnym węzłem sieci przestrzeni publicznych stał się również przebudowany placu przed gmachem Corazziego, widokowo powiązany przez główną aleję parkową z katedrą i następnie dworcem kolejowym. Atrakcyjne zależności przestrzenne wykształcone pomiędzy tymi wnętrzami można scharakteryzować jako synergiczne. Tak powstały układ dwóch placów wymiennie przejmuje tradycyjną funkcję miejsca spotkań - miejskiej agory.

Badając aspekty synergii warto podkreślić wartości synergii przestrzeni we wnętrzu urbanistycznym wytworzone przez nowy projekt fontann. Pawilon płynnie wyrastający z nawierzchni placu dzieli wnętrze na dwie niezależna przestrzenie, wzajemnie ze sobą sprzężone. Wytworzony układ przestrzenny pozwala na równoczesną i niezależną organizację imprez plenerowych dedykowanych dla odmiennych grup odbiorców, umożliwiając integrację uczestników.

Pole synergii Centrum Południe Dworzec -Plac Małgorzatki (MCSW Elektrownia). Południowa część śródmieścia posiada niewielkie pole synergii wytworzone wokół przestrzeni dworca. Sąsiedztwo dworca nadal niestety generuje nieznaczny wpływu na rozwój przyległych terenów. Potencjalne pole synergii równoważące północne centrum może wykształcić sie w oparciu o niewielki tzw. Plac Małgorzatki. O potencjale miejsca stanowi dogodna komunikacja i łatwy dostęp do ścisłego centrum, sąsiedztwo licznych placówek oświatowych skupionych wokół placu, oraz atrakcyjnie przekształconego budynku Mazowieckiego Centrum Sztuki Współczesnej Elektrownia (nagrodzonego w VII edycji konkursu „Życie w Architekturze”).Utworzona z inicjatywy A. Wajdy placówka kultury o randze ponadlokalnej prezentuje dorobek sztuki współczesnej, prowadzi aktywną działalność kulturalną w poprzemysłowych murach dawnej elektrowni i stanowi unikalny potencjał dający szanse na rozwój obszaru wg scenariusza krakowskiego Zabłocia (MOCAK).

Pole synergii Miasta Kazimierzowskiego. Obręb zabytkowego średniowiecznego układu, związanego z lokacją miasta przez Kazimierza Wielkiego, mimo znacznych wartości kulturowych i urbanistycznych pod koniec XX wieku w konsekwencji przekształceń gospodarczych i przestrzennych stał się obumarłą i powszechnie omijaną częścią miasta, wymagającą podjęcia intensywnych działań. Kluczowym projektem mającym na celu ożywienie obszaru jest zwycięski konkursowy projekt urbanistyczny na rewitalizację rynku wraz z kamienicą Deskurów (2015r). Praca autorstwa WCXA wg oceny jury „...oferuje rozwiązania charakteryzujące się wrażliwością przestrzenna $i$ estetyczną. Osnowa jest szacunek dla stanu istniejacego, który uwidacznia się w minimalistycznej formie interwencji... co w opinii Sadu Konkursowego tworzy korzystne tto dla historycznej, zabytkowej 
substancji ${ }^{\prime \prime l}$. Autorzy zwycięskiej pracy, jako jedni z dwóch zespołów, w budowaniu koncepcji w założeniach kompozycyjnych odnieśli się do całego układu ,ścieżki rozwojowej miasta" związanej z przenoszeniem na przestrzeni wieków ośrodka aktywności miejskiej w kierunku wschodnim. Kolejnym projektem, charakteryzującym się jako współczesna interpretacja wartości historycznych, czekającym na realizację w tym obszarze jest odbudowa Bramy Krakowskiej wraz z budynkiem usługowym, wg interesującego projektu (Pracownia Architektury Opaliński) wyłonionego w konkursie w 2011 roku. Budowa nowej strategii rewitalizacji w oparciu o miejski projekt: Ożywienie gospodarcze i zwiększenie atrakcyjności inwestycyjnej Miasta Kazimierzowskiego $w$ Radomiu, przygotowywany zgodnie z wymaganiami stawianymi w ustawie. Spotkania konsultacyjne do projektu skupiają się wokół różnych grup (interesariuszy rewitalizacji): mieszkańców, placówek kulturalnych, przedsiębiorców, organizowane na obszarze MK pokazały duży potencjał, zaangażowanie uczestników i społeczną świadomość potrzeby kontynuowania procesów rewitalizacji w tej niezwykle wartościowej, pod względem urbanistycznym i kulturowym, części miasta.

Wytworzenie pola synergii wokół MK jest istotne ze względu na konieczność wyprowadzenie obszaru ze stanu kryzysowego, wyeksponowania jego wartości jako wierzchołka wyznaczającego równoważący kierunek synergii między MK a atrakcyjnym górnym fragmentem ul. Żeromskiego.

\subsection{Starówka Bielsko-Biała}

Zabytkowy układ średniowiecznej Bielskiej Starówki skupiony wokół starego rynku, urbanistycznie jest zbliżony pod względem morfologicznym, kompozycyjnym i powierzchniowym do radomskiego Miasta Kazimierzowskiego, prezentując czytelny historycznie wykształcony układ miejski. Obszar był dotknięty również podobnymi problemami związanymi z degradacją zabudowy. Rewitalizacja obszaru miała być odpowiedzią na kryzys gospodarczy i pozwolić na przyspieszenie rozwoju miasta. Bielsko-Biała od początku lat 90 XX wieku prowadzi konsekwentnie działania remontowe, modernizacyjne i adaptacyjne w obszarze śródmieścia mające na celu rewitalizację tego obszaru. W latach 1996-97 powołano Zespół Koordynacyjny ds. Rewitalizacji Bielskiej Starówki, mający za zadanie wykonanie inwentaryzacji architektonicznej Starówki, rok później opracowany został Plan rewaloryzacji bielskiej starówki oraz Miejscowy Plan Zagospodarowania Przestrzennego Bielskiej Starówki. Działania zapisane w wspomnianych dokumentach uwzględniały zachowanie i uwypuklenie tożsamości historyczno-kulturowej. Zdobyte w ten sposób doświadczenia pozwoliły na efektywne przygotowanie i przyjęcie w 2004 programu "Nowa Starówka - Nowe Szanse". Zawarto w nim zasady zarządzania nieruchomościami i zwrócono uwagę na konieczność uporządkowanie spraw własnościowych. Program został skorelowany z innymi dokumentami strategicznymi i polityką mieszkaniową obowiązującą w mieście. Zawarte w nim projekty modernizacji i prac konserwatorskich dotyczyły odnowy całych kwartałów miejskich, nie tylko poszczególnych kamienic, były związane z tworzeniem spójnego systemu sieci przestrzeni publicznych. Najbardziej widocznym efektem programu była przebudowa płyty rynku, wg projektu Cempla M. W projekcie zachowano naturalne i szlachetne materiały, wyeksponowano historyczne elementy placu: fontanna, studnia, pomnik św. Jana Nepomucena oraz odkryte fundamenty wagi miejskiej. Opracowany w 2009 Program rewitalizacji obszarów miejskich Bielska-Białej na lata 2007

\footnotetext{
${ }^{1}$ Uzasadnienie sądu konkursowego dla wyboru I nagrody, 2016, przewodniczący sądu Szczepanik Dzikowski J.
} 
- 2013 był konsekwentną kontynuacją działań, zakładając ożywienie gospodarcze i społeczne oraz zwiększenie potencjału turystycznego na obszarze Starówki.

Powiązanie Starówki z wyłączoną z ruchu ul. 11 Listopada, która tworzy główną oś handlową i kulturalną, łączącą Bielską Starówkę z centrum Białej jest kolejną analogią do układu przestrzennego Radomia. Jest to szlak pieszy, który w zachowanym do dzisiaj układzie powstał w latach 1772-1785 i stanowił część traktu środkowo galicyjskiego, który prowadził od Śląska Cieszyńskiego, przez Kraków aż do Lwowa. W 2006 roku podjęto działania rewitalizacyjne polegające na wyłączeniu ruchu kołowego, wprowadzenie przejścia podziemnego. W wyniku podjętych działań obecnie stanowi atrakcyjną przestrzeń publiczną.

Należy zauważyć, że bielski projekt jest jednym z nielicznych przykładów konsekwentnie zrealizowanego programu rewitalizacji, który zakładał już na początku aspekt synergii rozumiany jako efekt „mnożnikowy” między poszczególnymi działaniami w mieście, nie tylko tymi dotyczącymi rewitalizacji. Dodatkowo działania rewitalizacyjne były sprzężone w czasie i obejmowały całe obszary miasta, Płytę Rynku, Plac Chrobrego, Plac Katedralny św. Mikołaja, ul. 11 Listopada, oraz tereny poprzemysłowe gdzie powstała największa galeria handlowa Sfera, w trakcie której realizacji podjęto się rewitalizacji odcinka rzeki Białki (wcześniej wykorzystywanego w przemyśle włókienniczym). Obecnie planowana jest rewitalizacja czterech parków.

Analizując przeprowadzone działania rewitalizacyjne można wyznaczyć zdefiniowane na początku główne pola synergii:

- skupione wokół Bielskiej Starówki,

- skupione wzdłuż ciągu ul. 11 Listopada,

- związane z lokalizacją galerii handlowej Sfera i rewitalizacją fragmentu bulwarów rzeki Białej.

Wzajemna relacja pomiędzy wspomnianymi projektami jest czytelna w przestrzeni śródmiejskiej i pokazuje korzystny wpływ wykształconych wartości synergicznych na tempo zmian w przestrzeni.

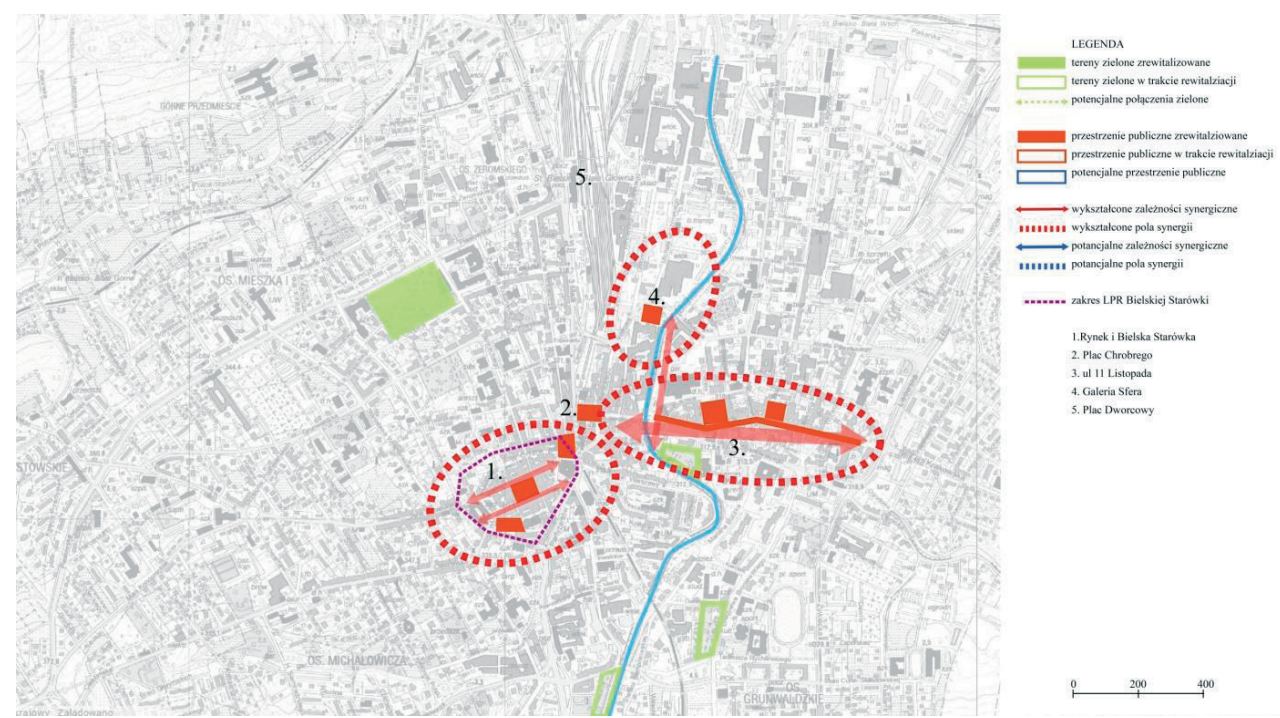

Rys. 4. Analiza wykształconych i potencjalnych zależności synergicznych Bielsko-Biała. Opracowanie własne 


\subsection{Przestrzenie historyczne Rzeszowa}

Przestrzenie historyczne Rzeszowa swoje początki, podobnie jak Radom, wiążą się z lokalizacją miasta przez Kazimierza Wielkiego. Obecna struktura przestrzenna Rzeszowa nadal charakteryzuje się wyraźnie wyodrębnionym, koncentrycznym historycznym układem, stanowiącym usługowe i komercyjne centrum miasta.

Opracowane w 2000 roku Studium Uwarunkowań i Kierunków Zagospodarowania Rzeszowa wyróżnia 10 obszarów strategicznych. Szczególne ważny dla procesu rewitalizacji jest obszar 1 CENTRUM, obejmujący Stare Miasto. Program rewitalizacji obszarów miejskich w Rzeszowie na lata 2007-2015 stanowi kontynuację Lokalnego Programu Rewitalizacji na lata 2004-2006, stawia cele strategiczne zakładające: poprawę jakości życia mieszkańców i standardów rozwiązań funkcjonalno - przestrzennych, tworzenie warunków dla zrównoważonego rozwoju gospodarki, wspieranie integracji społecznej i przeciwdziałanie wykluczeniu. Program określa obszary wsparcia wg poszczególnych kryteriów degradacji. W programie silnie zaznaczono rolę rewitalizacji obszarów miejskich wynikającą z roli miasta w krajowej i regionalnej strukturze przestrzennej.

Duży nacisk położono na rewitalizację licznych śródmiejskich przestrzeni zielonych parków miejskich. Jako priorytetowe dla wspomnianego obszaru jest nasycenie zielenią i nowoczesną tkanką miejską. Jako główne czynniki prowadzące do degradacji wskazano: niski poziom PKB w regionie, słaba atrakcyjność gospodarczą regionu - województwa. W ramach rewitalizacji śródmieścia za silny instrument sterujący zakłada się lokalizację nowoczesnych obiektów usługowo - handlowych pozwalające na generowanie strumieni ruchu pozwalających na właściwe funkcjonowanie centrum i uniknięcia przekształcenia w ,skansen dla turystów”. Program zakłada podnoszenie jakości przestrzeni publicznych wokół których buduje się miasto i tworzenie pomiędzy nimi sieci powiązań przestrzennych. Duży nacisk położono także na rewitalizację licznych przestrzeni zielonych - parków miejskich.

Obecnie planowana jest rewitalizacja ul. 3 Maja. Zorganizowany w 2015 r konkurs na plac Gancarski jest interesującym przykładem organizacji konkursu przez SARP na zamówienie prywatnego Inwestora. Zakres projektu dotyczył w znacznej część zabudowy placu budynkiem o mieszanej funkcji wraz z przedstawieniem koncepcji uporządkowania całego kwartału.

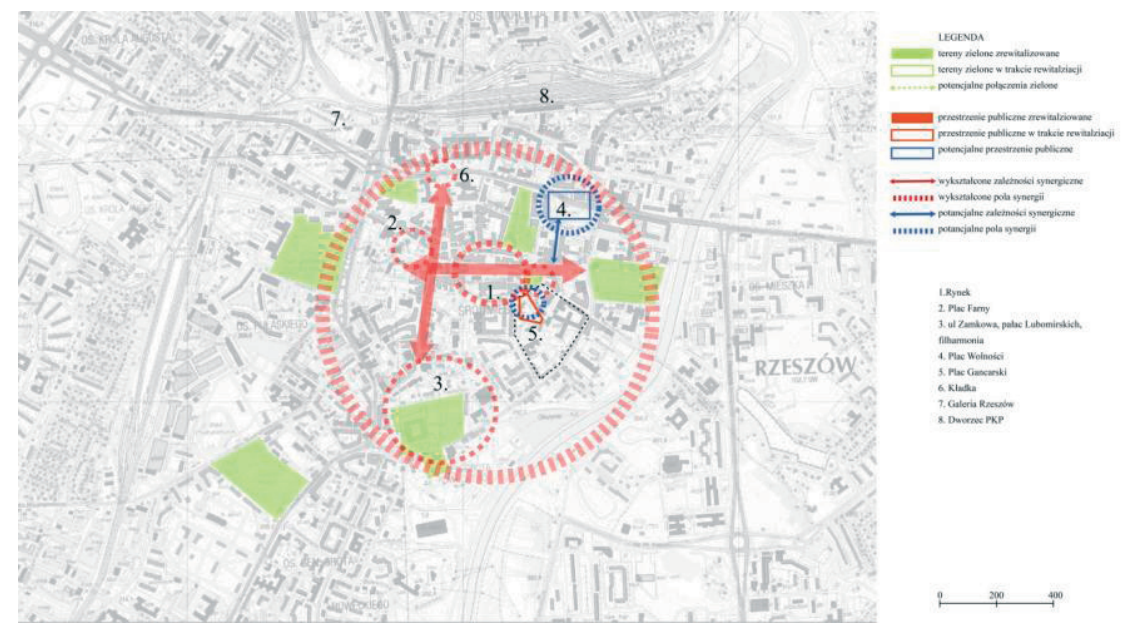

Rys. 5. Analiza wykształconych i potencjalnych zależności synergicznych Rzeszów. Opracowanie własne 
Potrzebę kompleksowej rewitalizacji historycznego centrum, jako skoordynowanych działań przedstawili radni (Kultys R. i Szumny W.),zwarty w proponowanym załączniku graficznym do założeń rewitalizacji. Przedstawiona koncepcja została oparta o sieć przestrzeni publicznych. Zdefiniowano główne ciągi piesze, przestrzeni placów miejskich wymagających rewitalizacji oraz lokalizację potencjalnych parkingów.

\section{Wnioski}

Analizując procesy rewitalizacji w przytoczonych przykładach tkanki historycznej miast średniej wielkości, należy zauważyć złożoność przeprowadzonego procesu, i podkreślić potrzebę ciągłości prowadzonych działań rewitalizacyjnych przynoszącą oczekiwane skutki (Bielsko-Biała). Efekty działań rewitalizacyjnych otrzymane na terenach o podobnej morfologii i zastanych procesach degradacji przynoszą różne efekty, zależne od specyfiki miejsca. Świadczy o tym sukces rewitalizacji Bielskiej Starówki zestawiony z wciąż trwającymi i niezbędnymi pracami rewitalizacyjnymi na obszarze Miasta Kazimierzowskiego.

Jacobs J. porównuje rozkład funkcji w mieście do partii szachowej, zaznaczając, że w mieście podobnie jak w szachach pionek może zmienić się w królową ${ }^{2}$. Podstawowa różnica polega na tym, że w mieście liczba figur nie jest ustalona zasadami, a przy odpowiednim ich rozstawieniu może ich przybywać. Uwzględnienie aspektu synergii między projektami i odpowiednie wpisanie w sieć przestrzeni publicznych na etapie strategii rewitalizacji prowadzi do uzyskania wspomnianych wcześniej efektów synergicznych„przybywania kolejnych pionków”. Zakładanie efektu synergii u podstaw planowania rewitalizacji sprzyja wzajemnej efektywności prowadzonych działań i pozwala szybciej osiągnąć niezbędny efekt mnożnikowy.

Zdefiniowane $\mathrm{w}$ artykule pojęcia określające pole synergii i kierunek synergii stanowią próbę zobrazowania zjawiska synergii w planowaniu rewitalizacji w budowaniu zależności między projektami a siecią przestrzeni publicznych.

\section{Literatura}

1. Gzell S. Europejskie miasto potrzebuje pomocy. Wiadomości konserwatorskie 44 (2015) 3343.

2. $\quad$ Gałka J., Grag N. Odnowa bielskiej starówki w opinii mieszkańców. 9 (2013) 205-213.

3. Przestrzenne aspekty rewitalizacji - śródmieścia, blokowiska, tereny poprzemysłowe, pokolejowe i powojskowe, IRM, Kraków, 2009.

4. Przykłady rewitalizacji miast, IRM, Kraków, 2009.

5. Böhm A.O budowie $i$ synergii wnętrz urbanistycznych. Wydawnictwo Politechniki Krakowskiej, Kraków, 1981.

6. Zuziak Z. Strategie rewitalziacji przestrzenie śródmiejskiej. Wydawnictwo Politechniki Krakowskiej, Kraków, 1998.

7. Jacobs J. Śmierć i życie wielkich miast Ameryki. Fundacja Centrum Architektury, Warszawa 2014.

8. Maj E. Radom w pótwieczu 1960-2010. Instytut Technologii Eksploatacji, Radom 2012.

9. Wojnarowska A. Rewitalizacja zdegradowanych obszarów miejskich. Wydawnictwo Uniwersytetu Łódzkiego, Łódź, 2011.

10. Lokalny Program Rewitalizacji Miasta Radomia na lata 2007-2013.

\footnotetext{
2 Jacobs J. „Życie i śmierć wielkich miast ameryki”, 2014
} 
11. Sprawozdanie z monitoringu Lokalnego Programu Rewitalizacji Miasta Radomia na lata 20072013.

12. Lokalny Program rewitalizacji Miasta Kazimierzowskiego.

13. Program Rewitalizacji Bielskiej Starówki.

14. Program Rewitalizacji Obszarów Miejskich w Rzeszowie na lata 2007-2015.

\title{
Synergy as a criterion \\ for evaluation of projects revitalization of city centers
}

\author{
Adam Derlatka \\ Department of Architecture, Cracow University of Technology, \\ Institute of Design of Cities and Regions, e-mail: aderlatka@gmail.com
}

\begin{abstract}
The purpose of this study was to discuss and analyze three projects of urban renewal within the city centre located in its cultural heritage. These projects were implemented as a part of revitalization programs and should result in a change of the entire degraded area. Consequently, the impact of these changes should bring synergy results to revitalize space and its surroundings. The paper focused on analysis and comparison of currently being developed revitalization programs in old town (Miasto Kazimierzowskie) of Radom and Rzeszów with already implemented project in Bielsko-Biała where synergy effect emerged thanks to very complex revitalization program. Another aim was to find out what is the potential synergy effect and how it can be achieved when preparing revitalization program for urban area placed in public area.
\end{abstract}

Keywords: Radom, urban regeneration, synergy, city center. 